\title{
Geology and Petrography of Basement Rocks around Tsauni, Northwestern Nigeria
}

\author{
M. Abdullahi ${ }^{{ }^{*}}$, M.A. Adediran ${ }^{2}$, and N.Y. Abdullahi ${ }^{1}$ \\ ${ }^{1}$ Geological Sciences, Faculty of Science, Federal University Gusau, Nigeria \\ ${ }^{2}$ Chemical and Geological Sciences, Al-Hikmah University Ilorin, Nigeria
}

\begin{abstract}
This work studied the geology and petrography of basement rocks around Tsauni and its environs with the main aim of establishing the different rock types present macroscopically and microscopically. The study area is part of sheet 54 Gusau NW, Northwestern Nigeria defined by latitude $12^{\circ} 12^{\prime} 00^{\prime \prime} \mathrm{N}$ and $12^{\circ} 9{ }^{\prime} 00^{\prime \prime} \mathrm{N}$ and longitude $6^{\circ} 43^{\prime} 30^{\prime \prime} E$ and 6 40'30"E. To achieve the aim, geological mapping was conducted in which fresh rock samples were collected and structures were studied and measured. The samples were subjected to petrographic analyses and their microscopic features were observed under the microscope. On the field, one major rock is encountered, granites (fine-medium grained and medium-coarse grained granites) while two minor rocks; quartz and xenoliths are mapped with the former being younger and the latter older than the granites. All the analyzed rocks are seen to contain quartz (40\%), orthoclase feldspar (40-50\%) and biotite (10-20\%). They are therefore said to be granites of the Older Granites of northwestern Nigeria believed to be of late Cambrian to lower Paleozoic in age. Strike-slip faults and joints were found as the structures associated with the rocks. Economically, these rocks can be best used in engineering constructions. There exist meandering rivers in the area enriching the inhabitants with surface water and presence of hand dug wells pinpointing the availability of groundwater. However, geophysical survey is recommended to back this up.
\end{abstract}

Keywords: Petrography, Tsauni, Granites, Xenoliths, Older Granites.

\section{INTRODUCTION}

The area under investigation lies within the Older Granites of the basement complex of Nigeria. A number of works have been done on the basement complex of Nigeria by various workers including [1-6] .

The rocks of the basement complex of Nigeria are broadly grouped into three and these include the MigmatiteGneiss Complex, the Schist Belts and the Older Granites. Some scholars like ${ }^{[6]}$ and ${ }^{[7]}$ have proposed different lithologic classifications for the complex. The lithology of the Migmatite-Gneiss Complex is varied but consists mainly of gneisses, migmatites and some older metasediments such as quartzites, carbonates, and mica schists of different

[8] as well as meta-igneous rocks of basic and ultra-basic compositions. The Schist Belts

narrow belts of metamorphosed volcanics and sediments within the migmatite-gneiss complex. The belts consist of various metasediments such as pellitic to semi-pellitic schists meta-conglomerates, quarzites, calcareous rocks, banded iron formations and mafic to ultra-mafic rocks (amphibolites). 
International Journal of Advances in Scientific Research and Engineering (ijasre), Vol 5 (4), April-2019

The Older Granites are the most obvious manifestation of the Pan-African orogeny and represent significant additions of materials (up to $70 \%$ in some places) to the crust ${ }^{[9]}$. Attempt to classify the Older Granites with respect to timing during an orogenic event are valid over only short distances. Contact features between members of the Older Granites suite suggest the coexistence of several magmas. Compositionally, the granites plot in the field of calc-alkaline rocks on the AFM diagram and although they contain significant amount of alkalis, are also often slightly corundum normative. Reference ${ }^{[10]}$ was of the opinion that the term "Pan African Granitoids" be used for the Older Granites not only on the merit of age which was not available at the time they were named Older Granites, but because it covers several important petrologic groups formed at the same time. The Older Granites occur intricately associated with the Migmatite-Gneiss Complex and the Schist Belts into which they generally intruded. Older Granite rocks therefore occur in most places where rocks of the Migmatite-Gneiss Complex or of the Schist Belt occur. According to ${ }^{[8]}$ there are three main groups of granites. These include an early phase, composing of granodiorite and quartz diorite, a main phase consisting of coarse porphyritic hornblende and syenite and lastly coarse porphyrite biotite granite. These are followed by a late phase comprising homogenous granite, pegmatite dykes and aplites. The early late phases are widely distributed

${ }^{[11]}$. This paper studies the geology and petrography of basement rocks found around Tsauni and its environs.

\section{II.LOCAL GEOLOGY}

The study area is located in Gusau Local Government, Northwest Nigeria. Northwestern Nigeria is underlain by gneisses, migmatites and metasediments of Precambrian age which were intruded by a series of granitic rocks of late Cambrian to lower Paleozoic age. The area is an integral part of sheet 54 Gusau NW, Northwestern Nigeria defined by latitude $12^{\circ} 12^{\prime} 00^{\prime \prime} \mathrm{N}$ and $12^{\circ} 9^{\prime} 00^{\prime \prime} \mathrm{N}$ and longitude $6^{\circ} 43^{\prime} 30^{\prime \prime} \mathrm{E}$ and $6^{\circ} 40^{\prime} 30^{\prime \prime} \mathrm{E}$. It consists mainly of basement complex rocks of the Older Granite type. The study area is dominantly underlain by granites. Minor rocks such as quartz are also encountered. There is paucity of scholarly work in the study area. 

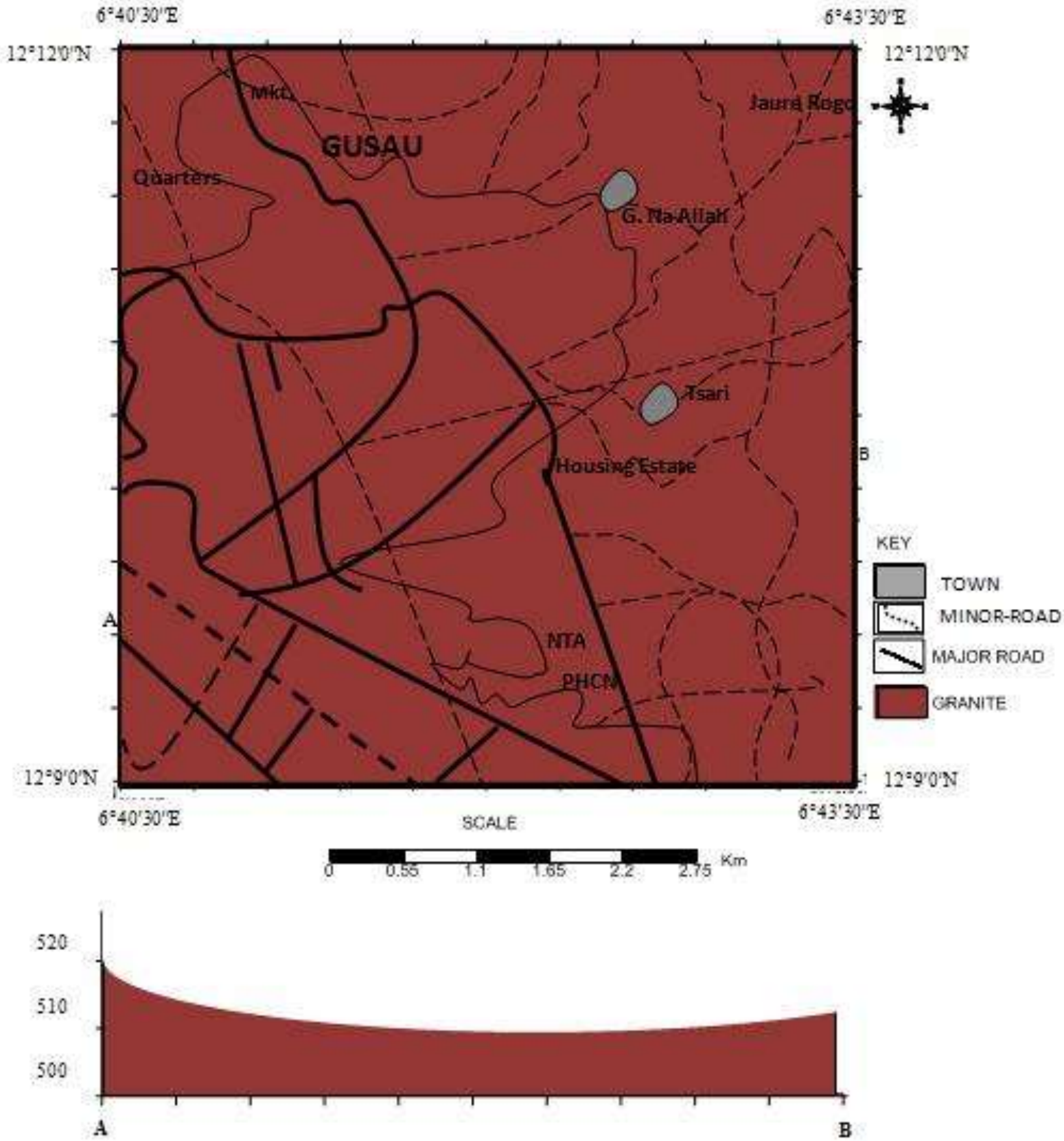

Figure 1: Geological Map of the Study Area and its Cross Section

\section{METHODOLOGY}

This work is restricted to geological and petrographic studies of basement rocks around Tsauni northwestern Nigeria. The study involves both field and laboratory activities. The field work lasted for six days after two days of reconnaissance studies. It involved detailed mapping, sampling, and description of the rocks encountered. In the course of mapping, a base map extracted from sheet 54 Gusau NW was used, G.P.S was employed for coordinate reading and compass clinometer was used to measure strikes and dips. Outcrop and rock exposures were located, studied and samples taken. Measurement and identification of structures such as joints, folds and faults etc. were carried out. Fresh rock samples were taken in the field from different outcrops encountered and used for thin sectioning. 
International Journal of Advances in Scientific Research and Engineering (ijasre), Vol 5 (4), April-2019

\section{IV.RESULTS/ DISCUSSION}

The study area is dominantly composed of one major rock type, the granites (medium grained granite and porphyritic granite). The encountered minor rocks in the area are quartz and xenoliths. The granites are described below as well as the minor rocks. The granites are described in three ways; field description, megascopic description and microscopic description.

\section{MAJOR ROCKS}

\section{V.I Medium-Coarse Grained Granite (Field Description)}

The medium-coarse grained granite is the most abundant rock type in the study area. It covers almost $85 \%$ extending to both north and south of the study area. It consists of quartz, feldspar and mica as the major mineral constituents. It is medium-coarse in texture. In the study area, these granites are somewhat weathered, structurally deformed and in most places occur in boulders. These granites were intruded by quartz in most of the outcrops.
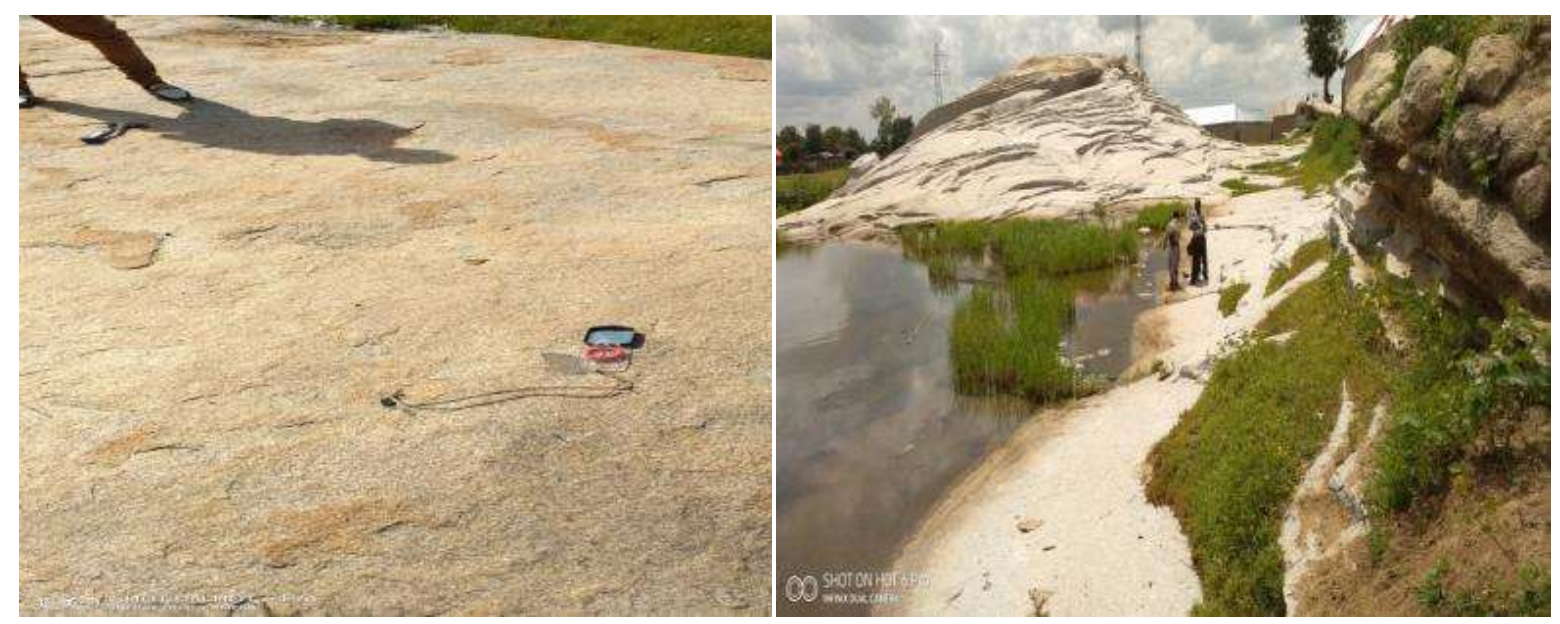

Plate 1: Medium- Coarse Granite Exposures

\subsection{Megascopic Description}

The rock observed in hand specimen is light grey in colour with medium-coarse grained texture. Minerals present are roughly K-feldspars (38\%), quartz (42\%) and biotite (20\%). Most of them are found adjacent to river channels.

\subsection{Microscopic Description}

Microscopically, three minerals quartz, orthoclase feldspar and biotite are observed under plane polarized light (PPL) and cross polarized light (XPL).

5.4 Quartz: Under plane polarized light, the quartz is blueish to milky with low relief and has anhedral form. Pleochroism is seen which is moderate. Inclusion, cleavage, extinction and interference are all absent in the quartz. It's colourless under cross polarized light. The quartz makes up to $40 \%$ of the rock.

5.5 Orthoclase: The orthoclase is light blue to milky in colour with medium relief, anhedral in form and has a tready (albite)/polysynthetic twins under plane polarized light. Inclusion, cleavage and extinction are absent. Moderate pleochroism is seen. The mineral is colourless under cross polarized light. The orthoclase takes up to $40 \%$ of the rock. 
International Journal of Advances in Scientific Research and Engineering (ijasre), Vol 5 (4), April-2019

5.6 Biotite: Under plane polarized light, the biotite is brown in colour with low relief and has a euhedral form. Two cleavage directions are seen in the biotite. The biotite remains brown under the cross polarized light. It makes up to $20 \%$ of the rock.

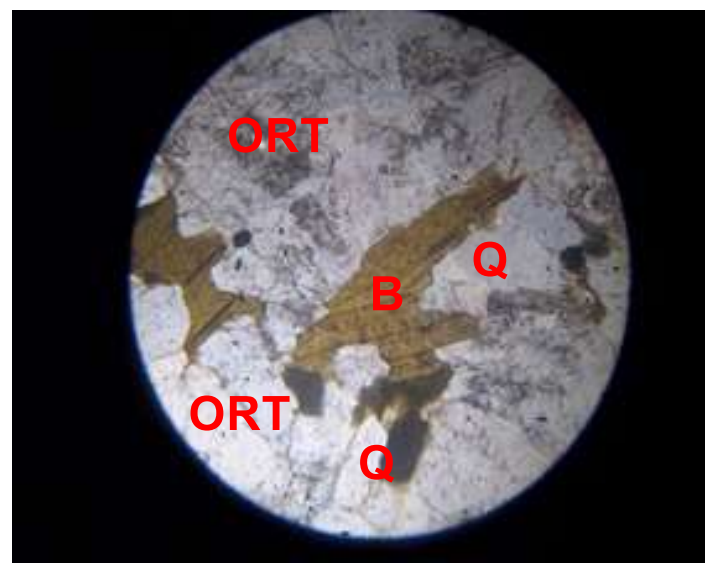

(A)

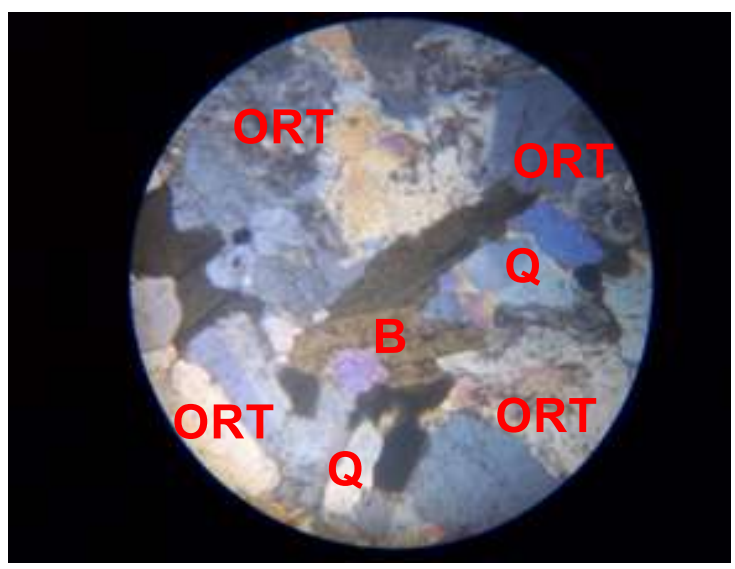

(B)

Plate 2: Photomicrograph of medium-coarse grained granite (A) under PPL and (B) under XPL B Biotite, Q-Quartz, ORT-Orthoclase feldspars.

\subsection{Fine- Medium Grained Granite (Field Description)}

This granite is well exposed and the second most abundant rock that outcropped in the study area. It occupies about $10 \%$. It is situated in the central part of the area being surrounded by the medium-coarse grained granites. The weathered parts of the rock are removed as a result of the construction activities of the inhabitants of the areas. It outcrops together with xenolith believed to have been an inclusion of pre-existing rock, which might either be derived from the country rock or may be a fragment of an earlier solidified portion of the rock having a slightly different composition.

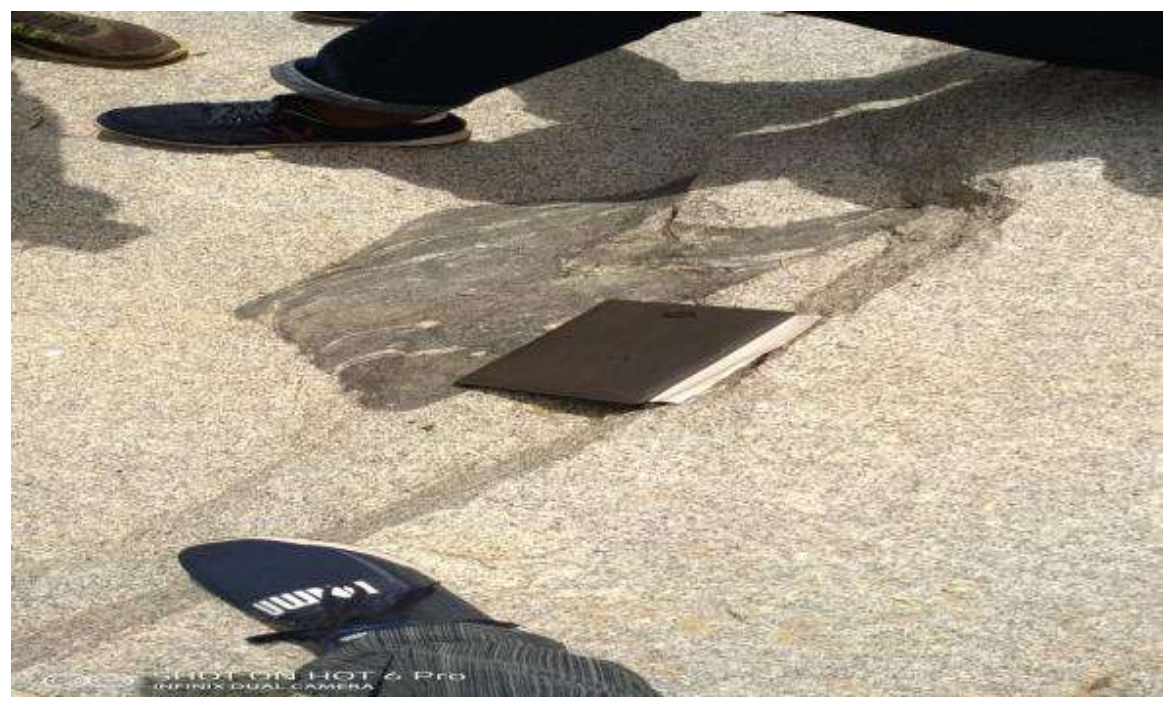

Plate 3: Fine-Medium Grained Granite Occurring with Xenoliths 


\subsection{Megascopic Description}

The granite observed in hand specimen is lighter than the first one in terms of colour with fine-medium grained texture. Minerals present are roughly K-feldspars (52\%), quartz (38) and biotite (10\%).

\subsection{Microscopic Description}

Viewed under the microscope, three minerals quartz, orthoclase-feldspar and biotite are observed.

Quartz: The quartz is blueish to milky with low relief and has anhedral form. It is moderately pleochroic. Inclusion, cleavage, extinction and interference are all absent. The Quartz takes up to $40 \%$ of the rock.

Orthoclase: The orthoclase is light blue to milky in colour with medium relief, anhedral in form and has hatchy/polysynthetic twins. It has no inclusion, cleavage and extinction. Pleochroism is moderate. The orthoclase makes up $50 \%$ of the rock.

Biotite: The biotite is dark to brown in colour with no relief and has a euhedral form. All the observed minerals are colourless under cross polarized light except for biotite which appears dark. Low pleochroism is also observed. It makes up $10 \%$ of the rock.

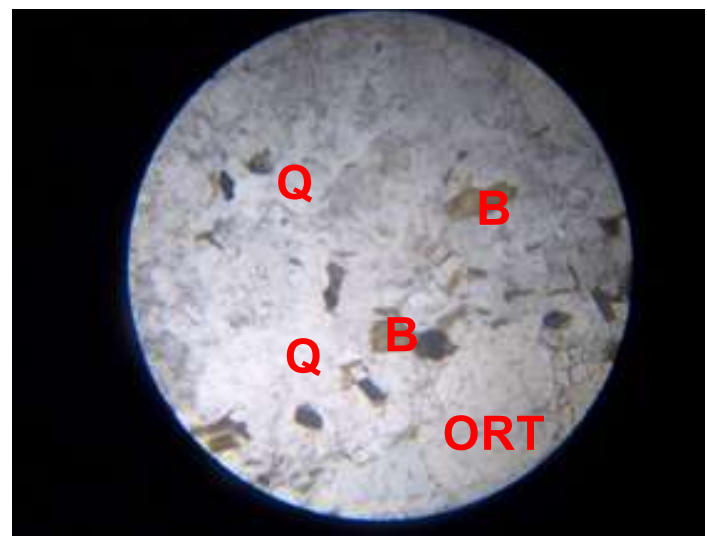

(A)

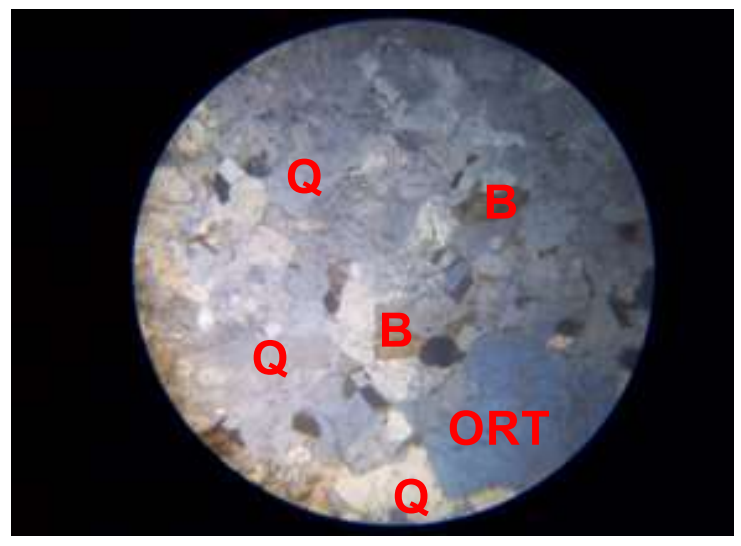

(B)

Plate 4: Photomicrograph of granite (a) under PPL and (b) under XPL B - Biotite, Q-Quartz, ORTOrthoclase feldspars.

\section{MINOR ROCKS}

\section{Quartz Veins}

Quartz veins are widely distributed in the study area. As the name implies, quartz veins contain single mineral, quartz. The quartz occurs along fractures or cracks on the medium-coarse granite exposures. The quartz veins are well visible occurring on the exposures and are highly resistance to weathering activities. The average width of the quartz vein observed is $2.1 \mathrm{~cm}$. 


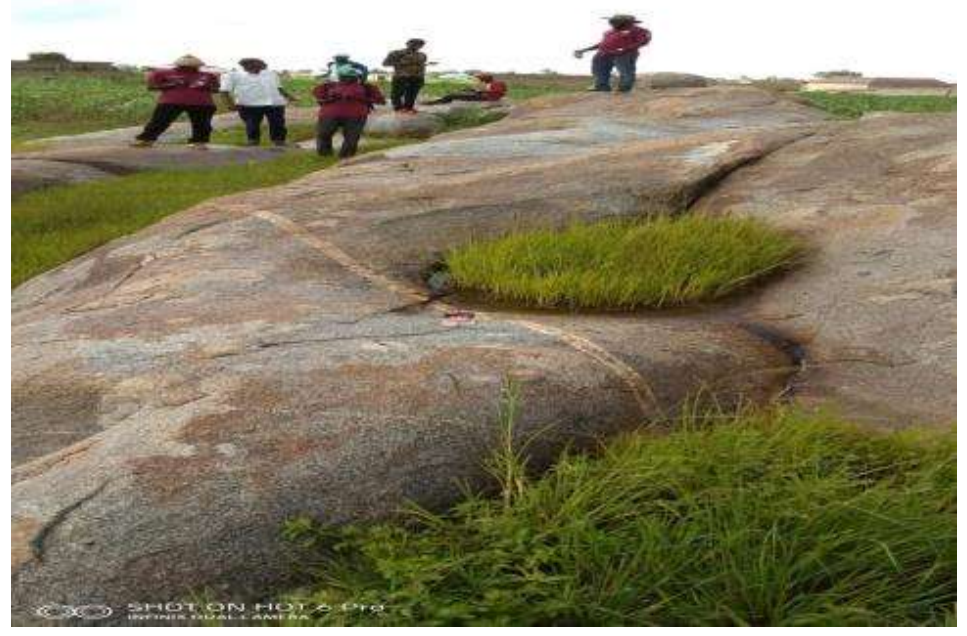

Plate 5: Quartz Veins in Granitic Rock

\section{Xenolith}

Xenoliths are sometimes referred to as "stranger rocks". It is an inclusion of pre-existing rock in an igneous or metamorphic rock. The fragment may be derived from the country rock or may be a fragment of an earlier solidified portion of the rock having a slightly different composition. In the mapped area, a number of xenoliths were identified occurring within the fine-medium grained granites (Plate 3).

\section{STRUCTURAL STYLES}

After the thorough geological mapping of the study area, numerous deformational structural styles were found associated with the abundant outcrops mentioned earlier. These include joints and faults. Plates $6 \mathrm{~A}$ and $6 \mathrm{~B}$ show these structures while plate 7 shows Rose diagram for trend of joints in the mapped area. From the diagram, the joints were observed dominantly trending $\mathrm{NE}$

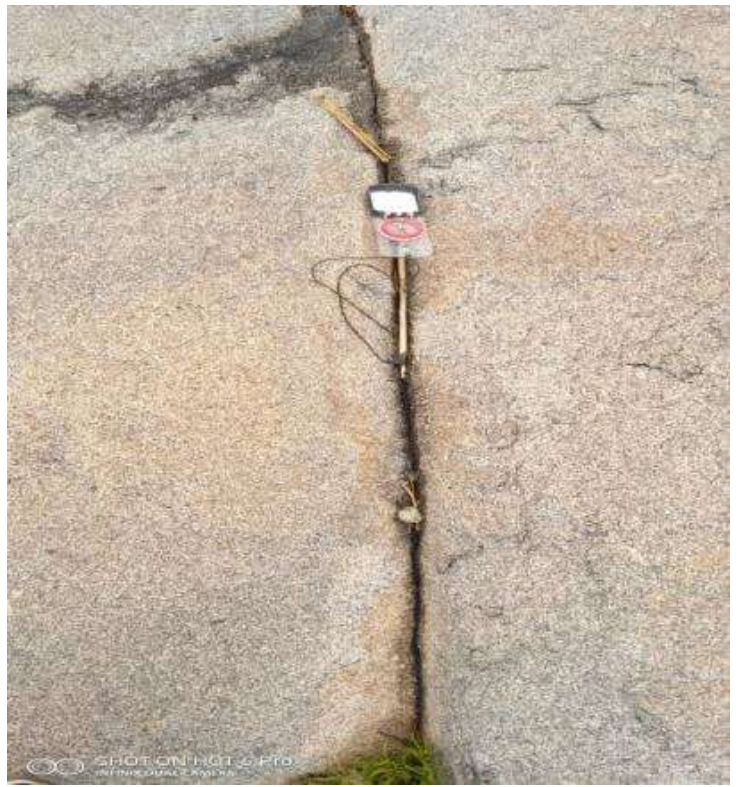

(A)

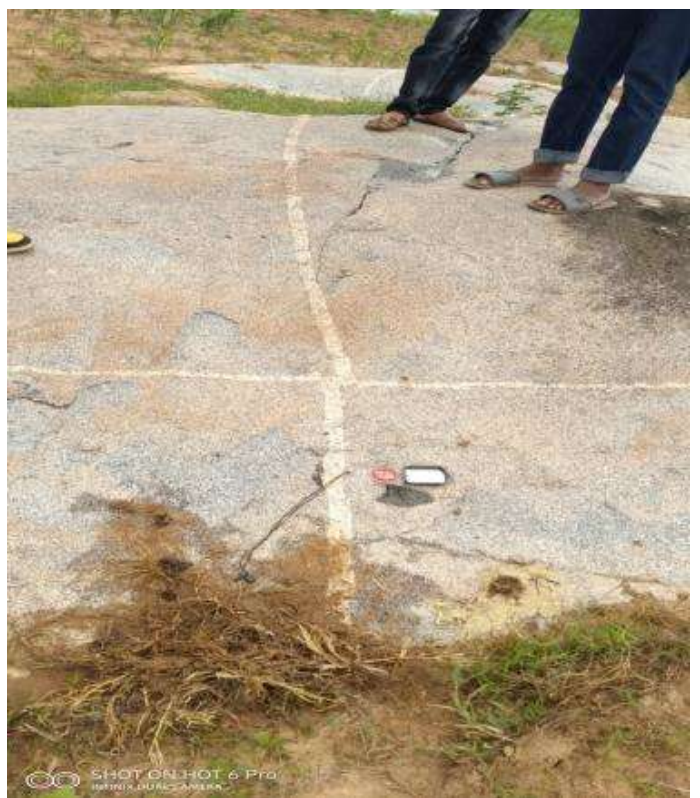

(B)

Plate 6 (A): Joint on Granite (12 ${ }^{\circ} 10^{\prime} 22.5^{\prime}{ }^{\prime} \mathrm{N}, 6^{\circ} 41^{\prime} 76.1$ 'E) (B): Strike-Slip Fault seen on quartz intruding granite. The quartz is chronologically younger $\left(12^{\circ} 12^{\prime} 00.5\right.$ '’ $\left.\mathrm{N}, 6^{\circ} 41^{\prime} 92.0^{\prime \prime} \mathrm{E}\right)$ 


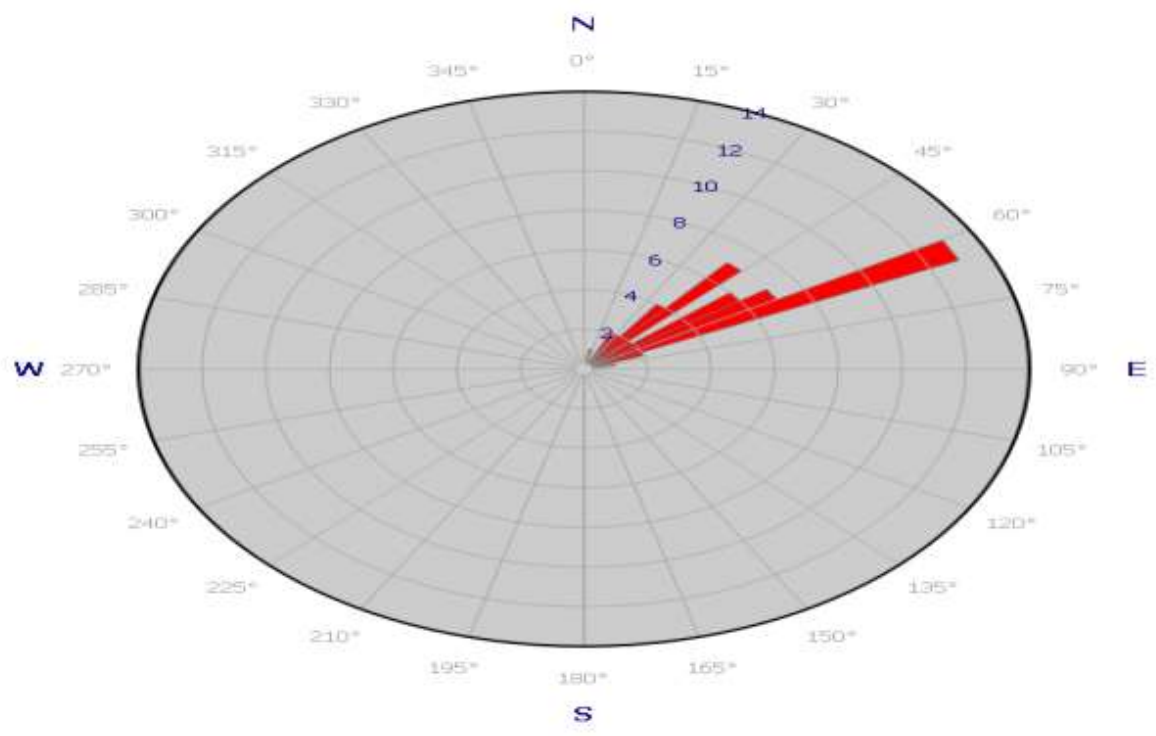

Plate 7: Rose Diagram for trend of joints in the mapped area

\section{CONCLUSION}

From the field mapping and petrographic analysis it is evident that the mapped area is underlain by rocks of the older granite of the Nigerian Basement Complex. The area been mapped is a basement terrain typical of the Nigeria Basement Complex of north-western Nigeria. The major rocks observed are medium-coarse grained and fine-medium grained granites. The minor rocks found are quartz and xenoliths. Structures, majorly faults and joints are encountered on the granites. The petrographic analysis of the rock samples reveals that the major constituents of the rocks are quartz, orthoclase and biotite in different proportions. This concluded that the analyzed rocks are all granites having different textures. Detailed geophysical and geotechnical studies should be employed to gain more knowledge on the geology, hydrogeology and suitability of the earth materials for engineering constructions respectively.

\section{REFERENCE}

1. M.A. Rahaman: Pre-Cambrian Geology of Nigeria. Paper presented at the Benin, Nigerian Geoltraverse International Meeting on Proterozoic Geology and Tectonic of high grade terrain programme and lecture series 28-30, 1988

2. M.N. Farghar: The Precambrian Geology of the 1:100,000 Sheet No.52 (Anka) Sokoto Province Geol. Surv. Nigeria. 1961

3. J.F. Trustwell: Report on the geology of crystalline Basement of 1:100,000. Geol. Surv. Nigeria, Rept. No. 1319. 1962

4. J.F. Truswell and R.N. Cope: The geology of part of the Niger and Zaria Provinces, Northern Nigeria. Geol. Surv. Nigeria Bull.29, 54p. 1963

5. P. McCurry: Pan-African Orogeny of Northern Nigeria. Bulletin Geol. Soc. American, 82, pp. 1971

6. M.O. Oyawoye: The Basement Complex of Nigeria, in Dessauvagie T.F.J. and Whiteman, A. J. (Eds) African Geology, University of Ibadan, pp.66-82, 1972

7. M.A. Rahaman: Recent advances in the study of the basement complex of Nigeria. Abstract, 1st Symposium on the Precambrian Geology of Nigeria, 1981 
International Journal of Advances in Scientific Research and Engineering (ijasre), Vol 5 (4), April-2019

8. H.A. Jones and R.D. Hockey: The geology of part of South-Western Nigeria. Geol Surv Niger Bull 31:101 pp. 1964

9. M.A. Rahaman: Recent advances in the study of the basement complex of Nigeria. In: P.O Oluyide et al. (1998). Precambrian Geology of Nigeria. Geological Survey of Nigeria, Kaduna. Pp 11-43, 1988

10. S.S. Dada: Proterozoic evolution of Nigeria. In: Oshi O (ed) The basement complex of Nigeria and its mineral resources (A Tribute to Prof. M. A. O. Rahaman). Akin Jinad \& Co. Ibadan, pp 29-44, 2006

11. A.A. Elueze and O.A. Okunlola: Petrochemical and Petrogenetic characteristics of metasedimentary rocks of Lokoja-Jakura Schist Belt, Central Nigeria. Journal of Mining and Geology, 39 (1): 21-27, 2003 